\title{
Studied on Species Diversity of Rice Leaf Folder and their Natural Enemies in North Eastern Coastal Plains of Odisha
}

\author{
B. K. Rautaray ${ }^{1}$, S. Bhattacharya ${ }^{2}$, D. Panigrahi ${ }^{3}$ and S. R. Dash ${ }^{4}$ \\ ${ }^{1}$ Krishi Vigyan Kendra, Jagatsinghpur (OUAT), India \\ ${ }^{2}$ Department of Plant Protection, VisvaBharati, India \\ ${ }^{3}$ RRTTS (OUAT), Mahisapat, India \\ ${ }^{4}$ KrishiVigyan Kendra, Malkangiri, India
}

*Corresponding author

\section{A B S T R A C T}

In this study the species diversity of rice leaf folder and their natural enemies were studied in three different blocks of Odisha and three Research stations of Odisha University Agriculture \& Technology, Bhubaneswar(under North Eastern Coastal plains) during the year 2015 and 2016 at different growth stages of paddy crop on the

\section{Keywords}

Diversity of rice, Leaf folder species, Predators,

Parasitoids

Article Info

Accepted: 07 September 2019 Available Online: 10 October 2019 basis of morphological characteristics, wing marking, coloration, characters of pronotum, subdorsal spots on prothorax and size of the larvae as described by Barrion and Litsinger (1991) etc. The study revealed that three rice leaffolder species were noticed i.e. Cnaphalocrocis medinalis (Guenée), Marasmia exigua (Bradley) and Brachimea arotraea (Meyrick) with the predominance of $C$. medinalis. Among the Leaffolder species, the highest population of Cnaphalocrocis medinalis (Guenée) $(83.34 \%)$, was recorded in each location followed by $M$. exigua $(12.22 \%)$ and $B$. arotraea $(4.43 \%)$ was very meager and all the three species were prevalent in all seasons. The common natural enemy fauna of rice leaf folder $C$. medinalis comprised of 10 species predatory arthropods. Out of which the predatory beetles belonging to the family Carabidae, Cocconellidae were dominant and among different parasitoids on rice leaf folder, the main spp. observed were, Macrocentrus philippinensis, Cotesia angustibasis and Goniozus spp, from larvae. The extent of parasitization was more in kharif season than in rabi. The mean parasitization during kharif $2015 \& 16$, rabi $2015 \& 16$ was in the order of 21.8 and 17.02 per cent respectively.

\section{Introduction}

Rice is one of the major sources of calories for half of the world's population. Rice is grown in more than 100 countries spread across six continents and in varying agro ecological and socioeconomic conditions. The eastern india, consisting of about $60 \%$ of rice growing area of the country (26.8 mha) possesses about 70 $\%$ of rainfed and including about $40 \%$ of low lying area. Rice is the staple food of Odisha. During 2015-16, rice was grown over an area 
of 40 mha with a total production of 104.32 million tonnes and average yield of $2570 \mathrm{~kg} /$ ha. Among the various biotic constrains to rice production, insect pests are of prime importance as the warm humid environment is conducive to survival and proliferation (Heong et al., 1995). Among the rice pests, lepidopterans cause considerable damage to rice crop and have major importance. Insect pests damage rice crop at different stages of crop growth of which leaf feeding insect pests are of major importance because of their ability to defoliate or to remove the chlorophyll content of the leaves leading to considerable reduction in yield.

Rice leaf folder, Cnaphalocrocis medinalis (Guen.) was considered as pests of minor importance have increased in abundance in late 1980's and have become major pests in many parts of India including Odisha. The yield loss is from 30 to 80 per cent due to leaf folder epidemic situation (Nanda et al., 1990; Han et al., 2015). Every unit of increase in infestation by $C$. medinalis decreased the yield by 14 and 1.46 per cent during summer and wet season, respectively. Currently, leaf folders Cnaphalocrocis medinalis, C. patnalis, $C$. ruralis and $C$. exigua have attained pest status on rice (Pandya et al., 1987). Cnaphalocrocis medinalis, Marasmiaexigua, $M$. patnalis and $M$. ruralis are the four superficially similar species common in rice ecosystem in Asia and Philippines. Similar to those present in the growing rice tracts of South and Southeast Asia (Khan et al., 1988; Barrion et al., 1991; Heong, 1993) and in entire Asia (Gurr et al., 2012). The discovery of Marasmiapatnalis by Bradley in 1981, first led to the realization that there was a complex of leaf folder species. In most of the rice eco systems studied more than one species of leaf folder exist in complex, thus the management of rice leaf folder is a complicated one. Hence, the identification of leaf folders fauna in Odisha is needed for the scientists to work out for an Eco-friendly Integrated Pest Management, thus it will support the ultimate beneficiary the farming community for better control measures of this important pest species. By keeping this, the present studies were planned with an objective to study the species diversity and the natural enemies of leaf folder in North Eastern Coastal plains of Odisha (Table 1).

\section{Materials and Methods}

\section{Species composition}

The study was conducted from four rice growing blocks (Badachana, Dharmsala, Bhadrak, Simulia and Baliapal) of three districts, rice research stations (Ranital, Baliapal and Badachana) at 15 days intervals to find out the leaf folder species diversity in the North Eastern Coastal plains of Odisha. Leaf folder larvae were collected from leaves and adults were collected by using sweep net. The specimens were brought to the laboratory and examined under binocular microscope. The diversity of leaf folder species was expressed in percentage. The leaffolder species were distinguished based on the larval and adult characters viz., forewing venation, coloration, characters of pronotum, subdorsal spots on prothorax and size of the larvae as described by Barrion and Litsinger (1991) and Reissig et al., (1985).

Adult moths of rice leaf folder were collected by using a light trap from the tillering to reproductive stages of the crop. The moths collected were brought to the laboratory and was examined under binocular microscope. The different species of Rice leaf folder were isolated based on wing venation, morphological features and size as described by Barrion and Lit singer (1985), Khan et al., (1988). Leaffolders moths were collected from different blocks and different research stations of OUAT situated in this region during July - 
2015 to Nov.2015 and Jan.2016-june.2016. The light trap fitted with mercury vapour lamp $(160 \mathrm{~W})$. All collected moths were killed using ethyl acetate in a killing jar. Moths were then pinned by spreading the wings in an insect spreading box for identification. The individuals belonging to the genera Cnaphalocrocis, Marasmia and Brachmia differ basically from each other in forewing venation and morphological characters. These morphological features are used to differentiate the leaf folder species. Cnaphalocrocis medinalis (Guenee) moth were golden yellow with dark brown marking on the both the wing on mid costa is closely resembles $M$. exigua moth were light yellow with a broad ' $\mathrm{C}$ ' shaped greyish brown band on terminal and sub terminal area of wing where as in case of $B$. arotraea the moths were yellowish white with whitish streak on the wings Finally the number of species was recorded separately and the percentage was find out.

\section{Natural Enemies of rice leaf folder}

Natural Enemies of Leaf Folders were collected monthly using sweep net.The observations were made on the important larval and pupal parasitoids and predators of leaf folders. And the extent of leaf folder larval parasitisation was studied during kharif 2015\&2016, and summer $2015 \& 2016$ at KVK, Jajpur. Leaf folder larvae were collected from the fields during the study period were transferred into glass tubes of size $15 \times 2 \mathrm{~cm}$. Leaf pieces of $5 \mathrm{~cm}$ length taken from the middle portion of the top leaves of 40 days old plants were provided for feeding, moistened cotton wool covered with filter paper cover was used to maintain the turgidity of leaf pieces. Every 24 hours leaf pieces were changed till the larvae pupated. The pupae were observed for the emergence of parasitoid which were identified under binocular microscope with help of Entomologist, at
OUAT insect laboratory and percent parasitisation was find out using following formula:

Parasitisation percentage $(\%)=$

Number of parasitized larvae

Total number of larvae collected

Species diversity $(\%)=$

Total no. of individuals of each species

x 100

Total number of individuals of all species

\section{Results and Discussion}

\section{Species Diversity}

During (2015\&16) survey conducted on species diversity of rice leaffolder by light trap and sweep net collected of leaffolder moths in North Eastern coastal plains districts of Odisha (Balesore, Bhadrak and jajpur),one regional research and technology transfer stations of OUAT and two Krishi Vigyankendras (Jajpur, Bhadrak) at 15 days interval and results are presented here under, three species of rice leaffolders i.e., $C$. medinalis, $M$. exigua and $B$. arotrea were encountered at different growth stages (Table 2). Among different districts, C. medinalis numbers ranged from 79.30 to 88.10 per cent with an average numbers of 83.34 per cent was noticed in different districts. The maximum numbers was found in Dharamsala (88.1\%) followed by Badachana (86.10\%), Chandabali $(82.10 \%)$, where as in Balesore district $(79.30 \%)$ C. medinalis was observed (Table 2 and Fig. 1). The M. exigua ranged from 8.40 to 17.20 per cent with an average numbers of 12.20 per cent was noticed in different districts. The maximum numbers of M. exigua was found in Bhadrak (16.80\%) 
followed by simulia (17.20\%), Chandabali (12.5\%) and Baliapal (12.1\%) (Table 2 and Fig. 1). The maximum numbers of B.arotrea was found in Baliapal $(8.0 \%)$ followed by Badachana (6.20\%), Chandabali $(5.40 \%)$ and Bhadrak (3.6 \%).Among the regional research stations and KVKs the dominant species was C. medinalis $(87.10 \%)$ followed by $M$. exigua $(12.10 \%)$ and B. arotrea $(5.60 \%)$. Padmavathi et al., (2006), Babyrani et al., (2007) also confirmed the dominance of $C$. medinalis in all rice agro eco systems in South and South Asia. The similar occurrence of leaf folder species complex with the dominance of $C$. medinalis was reported in Cuttack by Gunathilagaraj and Gopalan (1986) and Bhubaneswar by Mukherjee et al., 2008. The occurrence of $C$. medinalis was significantly more than $M$. exigua and $B$. arotrea irrespective of seasons and places.

The present study revealed that of $C$. medinalis was the dominant species than $M$. exigua and $B$. arotrea irrespective locations and places in coastal plains of Odisha. Mukherjee et al., (2008) was reported that three species of leaf-folder including, $C$. medinalis, $M$. exigua and $B$. arotrea were noticed among which $C$. medinalis is the dominant species. Padmavathi et al., (2006) also confirmed the dominance of $C$. medinalis in all rice agro eco systems in South and South Asia. The occurrence of leaffolder species complex with the dominance of $C$. medinalis was also reported in Cuttack by Gunathilagaraj and Gopalan (1986) and Bhubaneswar by Mukherjee et al., (2008). The occurrence of $C$. medinalis was significantly more than $M$ exigua and $B$. arotrea irrespective of seasons and places. In general, during kharif and Summer season harboured more $C$. medinalis population than $M$. exigua and $B$. arotrea. Among the leaffolders, $C$. medinalis, $M$. exigua and $B$. arotrea were predominantly collected from all surveyed places and such information was useful during 2015 to relook and identify the efficient management practices for the management of all the three species through rescreening of existing practices. Mathew and Menon (1984) reported that seven species of rice leaf-folder viz., C. medinalis, M. exigua (Butler), $M a$. billinialis (Hampson), Ma. patnalis, Ma. ruralis, Ma. suspicalis (Guenee), Bradina admixtalis (Walker) and gelechid leaf-folder, Brachmia arotraea (Meyrick) were found across the India.

\section{Natural enemies of rice leaf folder}

Cnaphalocrocis medinalis is the most important leaf folder species of rice crop and is attacked by a large number of natural enemies. In the present investigation during the study period on natural enemies complex (predators and parasitoids) in paddy ecosystem of north eastern coastal plain areas of Odisha are represented in the Table 3. The natural enemies were recorded on the crop from tillering stage to harvest of crop. A total of 8 predators were found associated with both the season rice crops and out of them the population of spiders out ranked all over predators. The dominant predators surveyed were the lady bird beetles, carabids and mirids were the most important natural enemies. Besides that dragon flies, damsel flies and predatory earwigs were also indentified as the Ariel predators of rice pests (Table 3). Other important natural enemies of the rice leaf folder recorded as parasitoid which belongs to the hymenopterans orders. The recorded hymenopterans were identified parasitoids such as, Trichogramma chilonis, T. japonicum (egg parasitoids), Cotesia angustibasis (Apanteles), Macrocentrus philippinesis (Ashmead), Goniozustrian gulifer (Kieffer), Xanthopimpla sp. and A. panteles sp. (Braconidae) (larval and pupal parasitoid of leaf folder) (Table 3).

In the present study, predators such as spiders, dragon and damselflies, mirid bugs, coccinellids, carabids and cicindellids were 
found throughout the crop growing period with little fluctuation in the three methods. However, spidres, dragonfly, damselfly and coccinellids were more during the vegetative stage of the crop, where asmirids, Staphylinids and Cerambycidae were more during reproductive stage of the crop. All the recorded predators and their population are known to be directly related to their prey population. These observations are in agreement with studies by Parrassapa et al., (2017), who reported peak population of spiders during tilleing stage. The present finding of domination of spiders among predators was in accordance with Bhattacharya et al., (2006), who reported 26 species of predators of which spiders and coccinellids were abundant. The predatory wealth of rice leaffolder was reported by Gunathilagaraj and Ganesh Kumar (1997) and revealed that dominant predators belong to Coleoptera, Arenae, Hymenoptera and Odonata. Vijay Kumar and Patil (2006) also confirmed the domination of spiders and mirids as predators in rice eco system.

Other important natural enemies of the rice leaf folder $C$. medinalis recorded at different stages of crop growth as parasitoid which belongs to the hymenopterans orders.

The recorded hymenopterans were identified parasitoids such as, Trichogramma chilonis, $T$. japonicum (egg parasitoids), Cotesia angustibasis (Apanteles), Macrocentrus philippinesis (Ashmead), Goniozustrian gulifer (Kieffer), Xanthopimpla sp. and Apanteles sp. (Braconidae) (larval and pupal parasitoid of leaf folder) (Table 4). During the study period $T$. japonicum and $T$. chilonis were observed as only egg parasitoids. It was earlier reported in India by Baby rani et al., (2007), Behera et al., (2006) and Rubaljot and
Brar (2008), the egg parasitoid Trichogramma species, the larval parasitoids Cadiochiles philippinensis, Apanteles spp, Goniozus spp, Copidosoma psisnacoleiae and Trichoma cnaphalocrocis Uchida and pupal parasitoid Xanthopimpla flavolineata Cameron and larval - pupal parasitoid Brachymeria spp were prevalent.

\section{Extent of parasitisation}

The extent of parasitisation of rice leaf folder studied from field collected leaffolder larvae during the both season kharif and summer crop of 2015and 2016 under north eastern coastal plains conditions. A comparative study on the extent of $C$. medinalis. $M$. exigua and $B$. arotraea revealed that the maximum parasitisation of 16.66 per cent was recorded on $C$. medinalis in the first fort night of October (Fig. 2).

The parasitisation gradually declined from mid-October reaching as low as 3.25 per cent towards fag end of November. In case of $M$. exigua the extent of parasitisation varied from 1.84 to 10.95 percent during the above period with a maximum of 10.95 per cent in the first fortnight of November. This was due to late appearance of $M$. exigua on wet season rice crop. The B. arotraea recorded 3.10 to 6.92 per cent parasitisation, the maximum being in the first fort night of October.

The parasitisation per cent gradually increased from first fort night of September with peak incidence in the first fortnight of October for $C$. medinalis and $B$. arotraea and then gradually decreased, thereafter. On the other hand, parasitisation of M.exigua commenced from first fortnight of November after which the population was declined. 
Table.1 Characteristics distinguishing larvae of $C$. medinalis and $M$ exigua and B. arotrea are listed below (DRR, 1987).

\begin{tabular}{|c|c|c|c|}
\hline \multirow{2}{*}{$\begin{array}{l}\text { Name of the } \\
\text { insect }\end{array}$} & \multirow{2}{*}{$\begin{array}{l}\text { Larval } \\
\text { instar }\end{array}$} & \multicolumn{2}{|r|}{ Characteristics } \\
\hline & & Duration(days) & \\
\hline C. medinalis & $1^{\mathrm{st}}$ & 3.5 & Head black, posterior notch of head capsule prominent \\
\hline M exigua & $1^{\mathrm{st}}$ & 4.5 & Head black flattened \\
\hline B. arotrea & $1^{\mathrm{st}}$ & 3.5 & Head and prothorax black \\
\hline C. medinalis & $2^{\text {nd }}$ & 4.0 & Head brown, faint brownish mark on protharacic shield \\
\hline М exigua & $2^{\text {nd }}$ & 3.5 & $\begin{array}{l}\text { Head light brown, faint brownish mark on prothoracic } \\
\text { shield absent }\end{array}$ \\
\hline B. arotrea & $2^{\text {nd }}$ & 3.2 & Head, pro and metathorax black \\
\hline C. medinalis & $3^{\text {rd }}$ & 4.0 & Brownish patch on either side of pronotum \\
\hline M exigua & $3^{\text {rd }}$ & 4.0 & Head light brown \\
\hline B. arotrea & $3^{\text {rd }}$ & 3.2 & $\begin{array}{l}\text { Head and pro thorax black, meso and metathorax light } \\
\text { black, a specific pattern of lines on the body which are } \\
\text { faintly marked }\end{array}$ \\
\hline C. medinalis & $4^{\text {th }}$ & 4.5 & Dark brown patches on pro thorax prominent \\
\hline M exigua & $4^{\text {th }}$ & 4.5 & Head light brown \\
\hline B. arotrea & $4^{\text {th }}$ & 3.2 & $\begin{array}{l}\text { Specific pattern of lines on body prominent and one } \\
\text { lateral and two medium white markings on meso and } \\
\text { metathorax observed }\end{array}$ \\
\hline C. medinalis & $5^{\text {th }}$ & 5.2 & $\begin{array}{l}\text { Brownish patches prominent on meso and metathoracic } \\
\text { segments also }\end{array}$ \\
\hline M exigua & $5^{\text {th }}$ & 4.5 & Head light brown \\
\hline B. arotrea & $5^{\text {th }}$ & 5.5 & Prothoracic shield chitinised. \\
\hline
\end{tabular}

Table.2 Species diversity of rice leaffolder in North Eastern Coastal plains of Odisha during 2015-16

\begin{tabular}{|l|l|l|l|c|c|c|c|}
\hline $\begin{array}{l}\text { S. } \\
\text { No }\end{array}$ & District & $\begin{array}{l}\text { Name of } \\
\text { Block }\end{array}$ & Locations & $\begin{array}{l}\text { Total no of } \\
\text { moths Collected }\end{array}$ & $\begin{array}{c}\text { C. medinalis } \\
(\mathbf{\%})\end{array}$ & $\begin{array}{c}\text { M.exigua } \\
(\mathbf{\%})\end{array}$ & $\begin{array}{c}\text { B.arotre } \\
\text { a(\%) }\end{array}$ \\
\hline 1 & Jajpur & Badachana & KVK, Jajpur Badachana & 201 & 87.1 & 10.8 & 2.1 \\
\hline 2 & Bhadrak & Ranital & $\begin{array}{l}\text { RRTTS, Ranital, } \\
\text { Bhadrak }\end{array}$ & 188 & 83.2 & 11.2 & 5.6 \\
\hline 3 & Balesore & Baliapal & KVK, Balesore & 192 & 84.3 & 12.1 & 3.6 \\
\hline 4 & Jajpur & Badachana & Badachana & 245 & 85.4 & 8.4 & 6.2 \\
\hline 5 & Jajpur & Dharamsala & Achyutpur & 195 & 88.1 & 10 & 1.9 \\
\hline 6 & Bhadrak & Bhadrak & Bhadrak & 205 & 80.6 & 15.8 & 3.6 \\
\hline 7 & Bhadrak & Chandbali & Chandbali & 285 & 82.1 & 12.5 & 5.4 \\
\hline 8 & Balesore & Simulia & Simulia & 235 & 79.3 & 17.2 & 3.5 \\
\hline 9 & Balesore & Baliapal & Baliapal & & 80 & 12 & 8 \\
\hline & Mean & & & & & & $\mathbf{8 3 . 3 4}$ \\
\hline
\end{tabular}


Table.3 Natural enemies (predators and parasitoids) of rice leaf folder in north eastern coastal plains of Odisha

\begin{tabular}{|c|c|c|c|c|c|}
\hline S.No & Common name & Name & Family & Order & Stage to predates \\
\hline 1 & Wolf spider & $\begin{array}{l}\text { Lycosapseudoannulata } \\
\text { (Boesenberg and Strand) }\end{array}$ & Lycosidae & Araneae & larvae and adults \\
\hline 2 & Lynx spider & $\begin{array}{c}\text { Oxyopesjananus } \\
\text { (Thorell) }\end{array}$ & Oxyopidae & Araneae & larvae and adults \\
\hline 3 & Orb spider & $\begin{array}{l}\text { Argiope catenulate } \\
\text { (Doleschall) }\end{array}$ & Aranidae & Araneae & larvae and adults \\
\hline 4 & Orb spider & $\begin{array}{l}\text { Araneusinustus } \\
\text { (L.koch) }\end{array}$ & Aranidae & Araneae & larvae and adults \\
\hline 5 & jumping spider & $\begin{array}{l}\text { Phidippus sp. } \\
\text { (Koch) }\end{array}$ & Salticidae & Araneae & larvae and adults \\
\hline 6 & $\begin{array}{l}\text { Lady bird } \\
\text { Beetles }\end{array}$ & Micraspiscrocea (Mulsant) & Coccinellidae & Coleoptera & egg and adult \\
\hline 7 & $\begin{array}{l}\text { Lady bird } \\
\text { Beetles }\end{array}$ & $\begin{array}{l}\text { Menochilussexmaculatus } \\
\text { (Fabricius, 1781) }\end{array}$ & Coccinellidae & Coleoptera & egg and adult \\
\hline 8 & $\begin{array}{l}\text { Lady bird } \\
\text { Beetles }\end{array}$ & $\begin{array}{c}\text { Coccinella } \\
\text { repanda (Thunberg) }\end{array}$ & Coccinellidae & Coleoptera & egg and adult \\
\hline 9 & Ground beetle & $\begin{array}{l}\text { Chlaeniusposticalis(Motsch } \\
\text { ulsky) }\end{array}$ & Carabidae & Coleoptera & larvae \\
\hline 10 & Ground beetle & $\begin{array}{c}\text { Ophineanigrofascinata } \\
\text { (Schmidt-Goebel) }\end{array}$ & Carabidae & Coleoptera & larvae \\
\hline 11 & Damselfly & $\begin{array}{c}\text { Agriocnemispygmaea (Ramb } \\
\text { ur) }\end{array}$ & Coenagrionidae & Zygoptera & Adult \\
\hline 12 & Dragon fly & $\begin{array}{l}\text { Orthetriumsabinasabina } \\
\text { (Drury) }\end{array}$ & Gomphidae & Anisoptera & Adult \\
\hline 13 & Scarlet Skimmer & Crocothemisservilia(Drury) & Coenagrionidae & Odonata & Adult \\
\hline 14 & Earwig & Euborelliastali(Dohrn) & Carcinophoridae & Dermaptera & Egg and larvae \\
\hline 15 & Crickets & M. vittaticollis(Stål) & Cerambycidae & Coleoptera & Egg \\
\hline \multirow[t]{2}{*}{16} & Mirid bugs & C. lividipennis(Reuter) & Miridae & Hemiptera & Egg \\
\hline & \multicolumn{5}{|c|}{ Parasitoids } \\
\hline 17 & & Trichogrammachilonis & Ichneumonidae & Hymenoptera & Egg parasitoides \\
\hline 18 & & Trichogrammajaponicum & Ichneumonidae & Hymenoptera & Egg parasitoides \\
\hline 19 & & tesiaangustibasis(Apanteles) & Braconidae & Hymenoptera & Larval parasitoides \\
\hline 20 & & $\begin{array}{l}\text { crocentrusphilippinesis } \\
\text { hmead) }\end{array}$ & Braconidae & Hymenoptera & Larval parasitoides \\
\hline 21 & & niozustriangulifer(Kieffer) & Bethylidae & Hymenoptera & Larval parasitoides \\
\hline 22 & & antelescypris(Nixon) & Braconidae & Hymenoptera & Larval parasitoides \\
\hline 23 & & achymeria sp. & Chalcidae & Hymenoptera & Pupalparasitoides \\
\hline 24 & & rdiochiles philippinesis & Braconidae & Hymenoptera & Larval parasitoides \\
\hline
\end{tabular}


Table.4 Estimation of Natural enemies (Predators) population of Rice Leaf folder C. medinalis under Coastal rice ecosystem

\begin{tabular}{|c|c|c|c|c|c|}
\hline \multirow[t]{3}{*}{ SI no } & \multirow[t]{3}{*}{ Name of Predators } & \multicolumn{4}{|c|}{ Predatory population $\left(\mathrm{nos} / \mathrm{m}^{2}\right)^{*}$} \\
\hline & & \multicolumn{2}{|c|}{ Wet Season 2015} & \multicolumn{2}{|c|}{ Summer 2016} \\
\hline & & $75 \mathrm{DAT}$ & 85DAT & 75DAT & 85DAT \\
\hline 1 & Spiders & 87.25 & 52.75 & 45.25 & 40.50 \\
\hline 2 & Lady bird beetle & 115.75 & 85.50 & 75.25 & 68.25 \\
\hline 3 & Carabid beetle & 35.25 & 28.50 & 28.25 & 32.75 \\
\hline 4 & Damselfly & 9.00 & 10.00 & 8.75 & 5.25 \\
\hline 5 & Dragon fly & 5.15 & 9.245 & 2.25 & 4.25 \\
\hline 6 & Earwig & 4.25 & 3.10 & 1.25 & 2.15 \\
\hline 7 & Crickets & 7.25 & 5.25 & 3.25 & 7.25 \\
\hline 8 & Mirid bugs & 18.25 & 16.85 & 24.25 & 19.40 \\
\hline
\end{tabular}

*Means of 4 quadrates of one square meter each.

Fig.1 Species diversity of rice leaf folder in North Eastern Coastal plains of Odisha (values in \%)

\section{Species diversity of rice leaffolder in North Eastern Coastal plains of Odisha}

nc. medinalis M.exigua $=$ B.arotrea $(\%)$

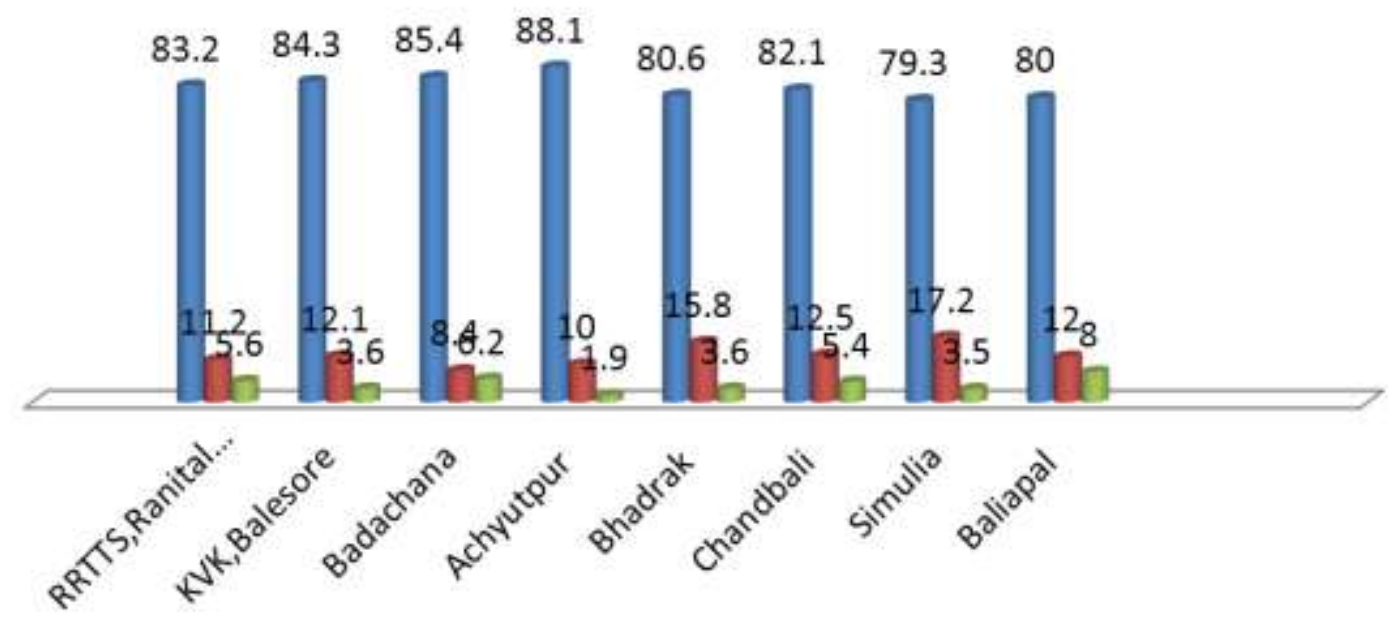


Table.5 Extent of Larval parasitisation (\%) of rice leaf folder larvae by different species of parasitoids

\begin{tabular}{|c|c|c|c|c|c|c|c|c|c|c|}
\hline \multirow[t]{2}{*}{$\begin{array}{l}\text { Sl } \\
\text { no }\end{array}$} & \multicolumn{5}{|c|}{$\begin{array}{c}\text { Extent of Larval parasitisation( }(\%) \text { in different growth } \\
\text { stages during Summer , 2015\&2016 }\end{array}$} & \multicolumn{5}{|c|}{$\begin{array}{c}\text { Extent of Larval parasitisation (\%) at different growth } \\
\text { stages of rice crops during Kharif } 2015 \& 16\end{array}$} \\
\hline & $\begin{array}{c}\text { Fort } \\
\text { night/Month }\end{array}$ & C.medinalis & M.exigua & B.arotraea & Total & $\begin{array}{c}\text { Fort } \\
\text { night/Month }\end{array}$ & C.medinalis & M.exigua & B.arotraea & Total \\
\hline 1 & Mar-I & 9.06 & 0 & 0 & 9.06 & Sept-I & 10.25 & 0 & 5 & 15.25 \\
\hline 2 & Mar-II & 11.02 & 0 & 6.83 & 17.85 & Sept-II & 15.95 & 1.84 & 4.45 & 22.24 \\
\hline 3 & Apr.-I & 10.25 & 2.15 & 4.6 & 17 & Oct-I & 17.88 & 3.15 & 6.92 & 27.95 \\
\hline 4 & Apr.-II & 9 & 11.2 & 4.01 & 24.21 & Oct-II & 14.3 & 10.13 & 5.85 & 30.28 \\
\hline 5 & May-I & 4.75 & 9.23 & 3.01 & 16.99 & Nov-I & 8.15 & 10.95 & 3.1 & 22.2 \\
\hline 6 & & & & & & Nov -II & 3.25 & 6.42 & 3.13 & 12.8 \\
\hline & Mean & & & & 17.02 & Mean & & & & 21.78 \\
\hline
\end{tabular}


Fig.2 Extent of larval parasitisation (\%) in different growth stages of rice crop

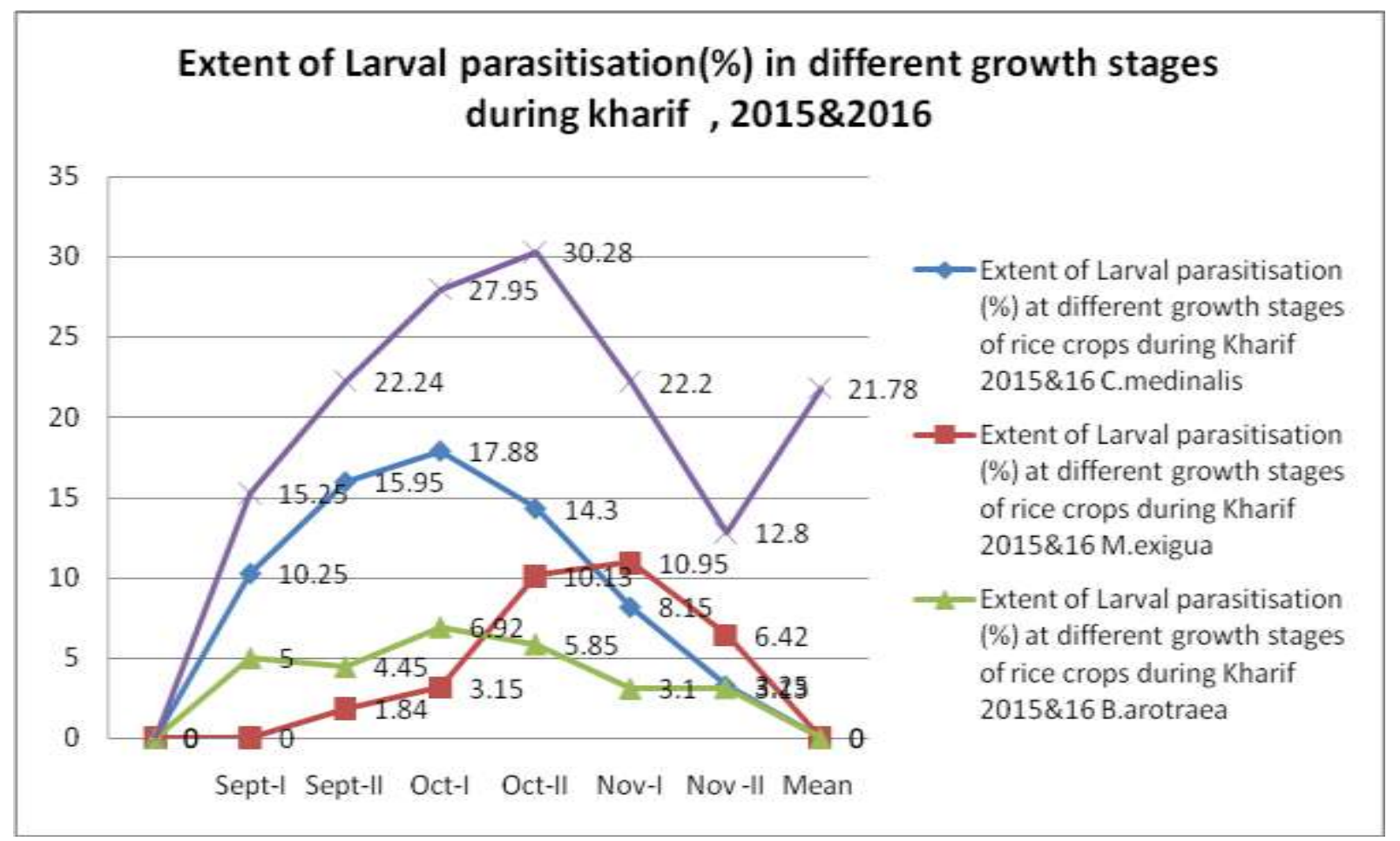

In summer season both the year data revealed that all the rice leaf folder species were vulnerable to attack by parasites. The extent of parasitisation by different parasites varied from 9.06 to 24.21 per cent. Parasitised larvae were available in the field from first fortnight of March for $C$. medinalis and B.arotraea while from first fortnight of April for M.exigua. The relative susceptibility of different species of leaf folders to parasite attack indicated that the extent of parasitisation comparatively higher in case of M.exigua followed by C.medinalis and B.arotraea.

As regards to the extent parasitisation of C.medinalis hardly 4.75 to 11.02 per cent larvae of various instars found by different parasites species under natural conditions. Higher parasitisation recorded during second fortnight of March. Due to late appearance of leaffolder species M.exigua, no parasitisation was recorded during March. Only 2.15 per cent larvae were found to be parasitised in the first fortnight of April which suddenly increased to 11.20 per cent in the second fortnight and parasitisation continued till May.

The extent of larval parasitisation of B.arotraea varied from 3.01 to 6.83 per cent, the maximum $(6.83 \%)$ being in the $2^{\text {nd }}$ fortnight of March. So the present finding of extent of parasitisation indicated that maximum parasitisation was recorded in the $2^{\text {nd }}$ fortnight of March followed by $1^{\text {st }}$ fortnight of April.

The species complex of rice leaffolder in different rice growing areas of Odisha was assessed on the basis of wing markings for adults. The present study indicated the occurrence of only three species viz., Cnaphalocrocis medinalis (Guenee), $\mathrm{i}$ (Bradley) and Brachmiaarotrea (Meyrick). Among them $C$. medinalis was the predominant species with 79.30 to 88.10 per cent incidence respectively. All the three species of rice leaf folder were found both the 
season in all locations of north eastern coastal plains of Odisha.

During the present investigation the different natural enemies that encountered on rice leaffolder were recorded at different intervals of crop growth. Among predators the abundance was in the order of spiders, cocinellidae, ground beetles, damsel flies, Dragon fly and earwigs. Among different parasitoids on rice leaffolder, main species observed were Trichogramma japonicum and T. chilonis from eggs, Macrocentrus philippinensis, Cotesiaangustibasis and Goniosus spp, from larvae, and Brachymeria from pupae. The extent of parasitisation in three seasons at different growth stages indicated that in Kharif season the per cent was more compared to Rabi. The mean parasitization during kharif $2015 \& 16$ and Rabi $2015 \& 16$ was in the order of 21.78 and 17.02 per cent, respectively.

\section{References}

Annual Report of Agriculture. Department of Agriculture and Cooperartion, Odisha. Area, production and yield of rice in Odisha. 2015-16,44.

Ane Noor Ul, Hussain Mubashar, 2016. Diversity of insect pests in major rice growing areas of the world. Journal of Entomology and Zoology Studies 2016; 4(1): 36-41

Baby Rani,W., Amutha, R., Muthulakshmi,S., Indira K. and Mareeswari, P. 2007. Diversity of Rice Leaf Folders and Their Natural Enemies. Research Journal of Agriculture and Biological Sciences, 3(5): 394-397

Barrion, A.T., Litsinger, J.A., Medina, E.B., Aguda, R.M., Bandong, J.P., Pantua, P.C., Viajante, V.D., Delta Cruz, C.G., Vega, C.R., Sorino, J.S., Jr. Camanag, E.E., Saxena, R.C., Tryon, E.H and Shepard, B.M. 1991. The rice
Cnaphalocrocis medinalis and Marasmia (Lepidoptera: Pyralidae) leaffolder complex in the Philippines: Taxonomy, bionomics and control, Philippines. Entomon. 8 (4): 987-1074.

Barrion, AT. and J.A Litsinger. 1985. Identification of rice leaffolders (LF) by wing markings. IRRN., 5(4): 24.

CRRI., 1982. Annual Report of 1982. Central Rice Research Institute, Cuttack, Orissa, India. pp: 164-168.

DRR. 1987. Characters to distinguish different species of rice leaf folder. Directorate of Rice Research, Rajendranagar, Hyderabad, pp.I-6.

Douresamy, S., M.S. Venugopal, P. Narayanan and M. Mohanasundaram. 1992. Rice leaffolder species in Pondicherry. Oryza, 29(4): 39.

Gunathilagaraj, K; Gopalan, M. (1986). Rice leaffolder (LF) complex in Madurai, Tamil Nadu, India. International-RiceResearch-Newsletter. 1986; 11(6): 24

Gurr, G.M., D.M.Y. Read, J.L.A. Catindig, J. Cheng, J. Liu, L.P. Lan and K.L. Heong. 2012. Parasitoids of the rice leaffolder Cnaphalocrocis medinalis (Guenee) and prospects for enhancing biological control with nectar plants. Review Article. Agricultural and Forest Entomology 14: 1-12.

Heong, K.C.,P.S. Teng and K.Moody.1995. Managing rice pests with lesschemicals.Geojournal.35:337-349.

Khan ZR, Barrion AT, Litsinger JA, Castilla NP, Joshi RC. 1988. A bibliography of rice leaf folders (Lepidoptera: Pyralidae). Insect Science and Applications.; 9: 129-174.

Mukherjee, S. K. Samalo, A. P. Mishra, P. R. Dash, A. N. 2008. Effect of environmental factors on the incidence of rice leaf-folders in costal Orissa conditions. Pest Management and Economic Zoology; 2008. 16(1): 4350. 
Nanda, V.K. and R.C. Bisoi, 1990.Bionomics of rice L7 C.M. Orissa J. Agrl. Res., 3(2): 130-135.

Pandya, H.V., S.A.H. Singh and M.S. Purohit. 1987. Yield loss caused by leaf folder damage alone and combined with yellow stem borer damage. Int. Rice. Res. Newsl., 12(5): 28.

Parasappa HH, Narasa Reddy G and Neelakanth. 2017. Rice insect pests and their natural enemies complex in different rice ecosystem of Cauvery command areas of Karnataka. Journal of Entomology and Zoology Studies, 5(5): 335-338

Reissig, W.H., E.A. Heinrichs, J.A. Litsinger, K. Moody, L. Fiedler, T.W. Mew and A.T. Barrion. 1985. Illustrated Guide to Integrated Pest Management in Rice in Tropical Asia. Int. Rice Res. Inst., P.O. Box. 933, Manila, Philippines,
411- 214.

SainiVarun., Singh Satyapriya, RawalRoomi and VenkateshYN.2017. Species diversity and distribution of Cnaphalocrocis and Scirpophaga (Lepidoptera: Crambidae) species complex in rice in Tamil Nadu, India. Journal of Entomology and Zoology Studies, 5(4): 1308-1313

Senapati B, Panda S.K. 1999. Rice stem borers in insect pests of cereals and their management. In: Prakash. A and J. Rao (Eds.). CRRI Cuttack, Orissa., 3-18.

Sivaraman, A. and Hari Prasad, Y.2012. Studies on leaf folder species complex and their damage potential of popular rice varieties in Cauvery Delta zone. International Journal of Current Research, 4(12): 552-554.

\section{How to cite this article:}

Rautaray, B. K., S. Bhattacharya, D. Panigrahi and Dash, S. R. 2019. Studied on Species Diversity of Rice Leaf Folder and their Natural Enemies in North Eastern Coastal Plains of Odisha. Int.J.Curr.Microbiol.App.Sci. 8(10): 634-645. doi: https://doi.org/10.20546/ijcmas.2019.810.072 